\title{
Towards the Integration of Mobile Phones in the Teaching of English Language in Secondary Schools in Akure, Nigeria
}

\author{
Ogunduyile, Abimbola. O \\ General Studies Department, the Federal University of Technology, Akure, Nigeria
}

\begin{abstract}
The advent of ICT comes with its attendant students' accessibility to information. Teaching these digital age $21^{\text {st }}$ century learners requires adaptive and technological induced methods by educators. The Global Satellite Mobile (GSM) provides learners greater accessibility to the internet which makes it easier for them to learn under certain controlled situations. This paper, therefore, investigated the possibilities of using mobile technology in the teaching and learning of the English language in secondary schools. The data was obtained from a three-week field experiment involving an English teacher and purposively selected twelve Senior Secondary School II students of the Federal University of Technology, Secondary School, Akure. The participants took part in activities involving different digital formats in the teaching and learning processes. Also, the respondents were interviewed to assess their perception and attitude towards this mode of teaching English Language. The paper analyses, within the framework of Communicative Language Teaching (CLT) approach to teaching and the Constructivist Theory of Learning, the collected data. The analysis revealed that the students and the teacher found teaching and learning very flexible and essential to their needs in this $21^{\text {st }}$ century. The paper concluded that M-learning promotes cooperative and collaborative learning through the enhancement of learners' use of authentic English language that would make it possible for them to construct their own knowledge. The integration of M-learning in to the teaching of English in secondary schools would afford the learners the opportunity of having a method that is $21^{\text {st }}$ century compliant and availing the learners the digital age benefits.
\end{abstract}

Index Terms-M-learning, mobile phones, communicative language teaching

\section{INTRODUCTION}

The rise of technology has given birth to a new breed of students whom Prensky (2001) calls 'digital natives' and Oblinger (2004) describes them as the 'net generation'. These students have enormous access to digital technology and they display a fluency and familiarity with the new technology. They speak the digital language of computers; the Internet and they share and produce digital contents such as blogs, digital images, video files and SMS messages (Tribe, 2004 in Duncan-Howell and Lee 2007). They observe that these students are growing with a glut of electronic media use and this differentiates them from previous generations of students whose learning experiences were dominated by text in books and journals. As they consume more images and sounds along with the text that they learn, they also interact with the technology more than previous generations.

The lives of these digital natives are influenced by mobile phones which seem to be the fastest growing technology in recent times. Wagner (2004) in Isiaka, Adewole and Olayemi (2011) aptly notes that 'the evidence of mobile penetration is irrefutable: cell phones, PDAs, Mp3 players, portable games, devices, handhelds, tablets and laptops abound. No demographic is immune from this phenomenon. People are increasingly connected and are digitally communicating with each other in ways that would have been impossible only a few years ago' $(\mathrm{p} 85)$.

The mobile phone which was introduced roughly 25 years ago, now has more than 6.6 billion connections in use (with an $80 \%$ penetration in the developing world) - serving a global population of 7 billion (Gaudry-Perkins and Dawes, 2011). There are more people using mobile phones in developing countries because of the poor economy and infrastructure. In Africa, it is reported that there are 649 million people who are mobile phone subscribers and in Nigeria, there are 93 million mobile phone subscribers, (BBC News, 2011) and younger people aged under 25 have been reported to be more users of the mobile phone than older people, (ITU,2011). Keegan (2005) notes that in the world (apart from the USA and Canada), 'it's the mobile that reigns, with countries often having 5 to 10 times the number of mobile phones than PC's' (p 100) and Gaudry-Perkins and Dawes (2011) also note 'in developing countries only $25 \%$ of the homes own computers' $(p 7)$. With the prevalence of mobile phones and more especially its handiness and its easy access to information for young people, especially secondary school students, it is obvious that these developments in information and communications technologies homes have (ICT) and evolving learner behaviours require educators to continuously review their approaches to pedagogy. With the increasing availability of low cost mobile phones, it seems appropriate to focus on the potentials of using the mobile technologies in teaching and learning practices in making education more accessible, more efficient, more cost-effective, and more enjoyable. With this view 
in mind, this study examines the teacher and students' perception of the use of mobile technologies in teaching and learning of the English language in The Federal University of Technology Secondary School, Akure.

\section{LITERATURE REVIEW}

\section{M-learning: Teaching and Learning through Mobile Technologies}

Teaching and learning through Mobile Technologies (MT) is called M-learning. It allows learning in no fixed location or time of learning (Kinshuk, 2003). It is a type of teaching and learning that allows for flexibility and ubiquity. It allows for a more student centred approach in learning where the student is more responsible for acquiring, processing and using information. It also allows for increased interactivity between teachers and students, thereby making teaching and learning a more personal activity. Nyiri (2002) defines M-learning "as learning that arises in the course of person-to-person mobile communication" (p.2). This type of pedagogy involves the use of phones, Ipods, Personal Digital Assistants (PDAs), it does not however include the laptop because the laptop though is portable, it is not mobile. Gaudry-Perkins and Dawes, (2011) state that mobile learning ranges from "simple SMS messaging, MMS live classroom sessions, web and podcasting to audio-to-text or text-to- audio applications, and it can provide enriched learning experiences via "educational video, logical reasoning and problem solving aptitude games, and even mobile whiteboards for interactive discussions." (p.7)

Teaching and learning through mobile technologies afford the option of mobility both due to the structure of the device and of the participants involved. This distinctive feature offers a transition from the occasional, supplemental use of computer labs, to frequent and integral use of portable computational technology (Roschelle, 2003). It bridges the gap between formal and informal learning. Similarly, it allows an increased mobility of population and lifelong learning, thereby creating opportunities for constant practice anywhere and anytime. This access to technology is important especially in the teaching of English language as a second language (12) because it enables the learners to constantly practice the language. It also aids the easy recollection of what has been taught thereby making it possible for learners to put into practice the learnt concepts in real life situations. In addition, it allows for variety and creativity in teaching and learning thereby increasing interaction and interactivity between teachers and students which brings about creativity and critical thinking. Furthermore, it allows the student to be more responsible in his acquisition of information; he is more active in getting his own education (Kukulska-Hulme, Shield \& Hassan, 2010). M-learning is often regarded as a subset of e-learning and is seen as good supplement to e-learning or face to face interaction. M-learning can never replace traditional education or the role of teachers, it is a tool that can help to make tremendous impact on education more accessible, more efficient, more cost-effective especially in developing countries, and more enjoyable.

Although using mobile technologies in education is a fairly new field when compared to areas like health and agriculture, various studies have been carried out to examine the viability of using mobile technologies for pedagogical activities in educational institutions. Several studies, Geddes (2004), Hartnell-Young and Heym (2008), Perkins and Dawes (2011) have examined the benefits of using mobile technologies for pedagogical purposes. These studies describe teaching and learning through the mobile technologies as a very good way of making the students active participants in the acquisition and dissemination of knowledge. Nyíri (2005) examines the intimate connection between communication and education and submits that it is in the heart of communication not just through words but pictures that m-learning is realised. Mellow (2001) views m-learning as a means for enhancing the broader learning experience and a primary method for delivering courses for distance learning, he also views m-learning as a powerful method for engaging learners on their own terms. Sebbowa (2012) investigates the role of mobile phone forums in enhancing interactivity in teaching in Makerere University, Uganda. She considers mobile phone forums as appropriate in the large class situations in the African educational situation and her findings indicate that mobile phone forums indeed enhance interactivity and collaboration between teachers and students.

In using mobile technologies as a tool to teach English language, Mohammed and Woollard (2009) suggest ways in which teaching and learning the English Language through the mobile phone can be effectively carried out in high schools to ensure maximum benefit for both the teachers and the learners. Nwocha (2010) carried out an actual research using SMS based mobile learning system to teach Elish to high school students who live in a rural area in Northern Nigeria and she records that when tested, the students under experiment performed better than the ones who were taught in traditional based classrooms. Clarke et al (2008) also studied the viability and the acceptance of using the SMS based learning system to teach and engage students in language learning. Some students were selected in Hong Kong University of China and the findings showed that the students found it worthwhile and engaging and it helped them in their acquisition and retention of the language taught via this learning system.

\section{THEORETICAL CONSIDERATIONS}

The current study situates m-learning in the Communicative Language Teaching (CLT) approach to teaching and the Constructivist Theory of Learning. CLT aims at developing real-life communication skills in learner. The primary goal of CLT is to provide students with the functional ability to perform competently outside of the language classroom (AlMutawa and Kailani, 1989). This approach sees the teacher as a facilitator in language tasks and activities, rather than dominating a tightly controlled language lesson. In this learner-centred environment, students develop autonomy in 
cooperative and collaborative tasks which enable them to continue to learn in real-world contexts. Constructivism construes learning as a process in which the learner actively constructs or builds new ideas or concepts. It is also known as social constructivism which indicates that knowledge is constructed when individual engage socially in talk and activity about shared problems or task. Versions of Constructivism include Active learning and Discovery learning. At any rate, the learner is expected to be actively involved, which makes it learner-centred. This of course does not do away with the presence of a teacher, but the presence of a highly creative and imaginative teacher is needed to make teaching and learning successful. M-learning is a learner-centred endeavour, it is collaborative, interactive and cooperative. These features conform to the principles of communicative language teaching and constructivist theory of learning.

\section{Methodology}

The data for this study was obtained through experiment involving purposively selected 12 SS2 students of Federal University of Technology secondary School, Akure who had mobile phones which could browse the internet and could receive and send out multimedia contents. The popular $2 \mathrm{go}$, which is a mobile chat application used by young people to chat with friends both on a one on one basis and in groups, was used as a test run because it is popular and the students are all familiar with it and it was very easy to get it installed on their phones. Furthermore, a blog which is meant for posting assignments in the various aspects in English was created and could easily be accessed through their phones. A group forum on Facebook was also created for the students to access questions and instructions on what to do. Questions were posted on the blog and the students were told to respond to the questions. Interviews were also conducted with the teacher and the students to determine their attitude towards using the mobile phone for pedagogical purposes. The sampled students were taught using different formats of digital media: audio format, mobile chat applications, SMS-ing and the use of blogs/forum. Different aspects of the English Language were taught to the students: Grammar, Oral English and Comprehension. These activities were given in order to test the potentials of $\mathrm{m}$-learning: variety, interactivity, flexibility and active participation in information acquisition. The following digital media were used: audio (amr, mp4), SMS, mobile chat, and use of search engines such as the google to browse and get information.

Under comprehension, a brief introduction of the topic 'summary' was read and recorded by the teacher and sent to the students via blue tooth. The students were instructed to go to browse up more information about summary and they were directed to go to a specific website www.endnote.com to get the information on the topic. The students were asked browse independently on some aspects of grammar and answer some questions that were posted on a forum created in Facebook. The teacher/researcher posted a comprehension passage and an exercise on pronunciation; the students were requested to answer the questions and send the answers through SMS or through 2 go. The teacher/researcher sent a few words to the students via the mobile chat application and they were instructed to read those words, pronounce them and send them back to the teacher via 2 go. The teacher/researcher listened to the words and sent the corrections to them through 2 go.

In addition to the assignments handed to the students, there were group and one to one chats with the students to discuss the questions given to them. Interviews were also conducted on a one to one basis and in group chats to view the perception of the teacher and the students on the use of the mobile technology for pedagogical purposes. The participants were asked some questions and the analyses that follow shortly reveal the participants' answers to the questions.

\section{DiscusSION OF FINDINGS}

The analysis that follows substantiate the feasibility, preferences, types of digital formats and the inherent merits and demerits of using mobile technology in the teaching of English language in a secondary school.

\section{A. Usefulness of Mobile Technology}

The researcher interviewed both the English teacher and the students on the inherent benefits derivable from the use of mobile telephone in the teaching and learning processes. The feedbacks from the respondents are treated under the following categories:

All the respondents (a teacher and 12 students) agreed that mobile learning is an easy method of teaching and learning in that one would not have to be in a particular setting in teaching or passing information to learners. It allows both of them to work at their own pace under a relaxed atmosphere thereby reducing the anxiety level of learners. The learners could be on their beds or dining tables yet actively be involved in learning. The teacher also found the technology especially, the mobile chat application, easy because of its mobility. The mobile technology made it possible for the teacher to play the role of a facilitator of knowledge rather than being the sole giver of knowledge.

Also, M-learning makes teaching and learning very flexible. This flexibility depends on the parties involved. The students found it flexible because they could easily use the format they enjoyed or found most comfortable to deliver their assignments. For example, the students could send information to the group either on facebook or via SMS. On the part of the teacher, he found teaching with the mobile phone very flexible. This is because she could decide what format to use in teaching students who had constraints like network problems or who had problems with the subscribed 
format of use. He could ask the students to answer questions on the comprehension and pronunciation exercises on SMS or on audio format. The students would depend on the promptings of the teacher on the choice of format.

Furthermore, it was observed that the internet helps the students to get information that they need. Mobile teaching helped the respondents to source for information independently thereby making them more active in their knowledge acquisition. Furthermore, the students found it quite challenging and exciting to find information themselves. Some of them found accessing information on Google challenging but with time they were able to get the information they needed. The teacher was more of a facilitator in the teaching and learning process. The students were more responsible in accessing information they needed on topics assigned to them in the English Language. The teacher helped only in clarifying issues that they did not quite get right.

Additionally, it was observed that teaching through mobile learning helped in increasing interaction and interactivity between the students in that they felt more comfortable in expressing themselves than in the stiff and formal classroom settings. Unlike the past where teachers and students do not relate informally, it was noticed that mobile technology facilitated a more friendly teacher and students relationship than was obtainable in a stiff formal setting. The students found learning through the mobile platform very engaging and very interactive with their teacher and amongst themselves than in the traditional chalk and talk method of teaching.

\section{B. Limitations of Mobile Technology}

Irrespective of the inherent advantages which mobile technology offers the teaching and learning of the English language, we have, however, identified some limitations to its effectiveness and efficiency. These are:

First, the students complained of the network problems during their attempts to log into the internet because of the poor network. It took a lot of time before the students could surf the internet. Second, the researcher discovered that the students' attention span was not more than an hour. They often got distracted and they had to be reminded that they were in a class and needed to read and type when necessary. Some of the participants felt that it was because they used $2 \mathrm{go}$ as a social chat room that was why it seemed very difficult to sustain the mindset that they were in a virtual teaching environment and so it would be better if another application was created solely for educational purposes The students also admitted that they were often distracted by the chats of other people and even by their family as they were often called to go and do one thing or the other. Third, it was noticed that the students often resorted to using textese, SMS style of writing and this already had begun to reflect in their assignments and despite all warnings to desist from using the language, they still used it unconsciously. Finally, Funding teaching through the mobile phone was expensive. The students cannot be expected to pay for the airtime used to learn and the salary of a teacher will not be able to cater for the cost of mobile teaching.

\section{Preferentiality}

On whether the respondents would prefer teaching with mobile technology to face to face teaching or a blend of both. It was discovered that all the participants preferred the use of both methods of teaching due to their firm belief that some aspects of the English language cannot be effectively taught through the mobile phone. Some of the areas mentioned by the students include English clauses and oral English. According to the students, they would need the face -to-face method of teaching to be able to overcome the seemingly challenges posed by those aspects of the English language. Similarly, the teacher also preferred the blending of both aspects but with a proviso that as long as both parties are aware of the rules of engagement and the ethics of using the mobile technology to teach the English language. Using both methods of learning, according to the teacher would be good because it incorporates what the students enjoy and what is already on ground, thereby increasing learners' interest in learning.

\section{Choice of Digital Format}

On what choice of digital media format would the teacher and students would like to teach and be taught the English language. The data analysis revealed that the participants preferred the use of browsing and the mobile chat application. They also preferred the use of games and audio format because they are capable of eliciting excitement and stimulating the interest of the learners.

\section{CONCLUSION}

The paper concludes that M-learning is cooperative, collaborative and learner centred. It enhances active involvement of the students in the acquisition of linguistic knowledge as it gives the learners the chance through networks and different forums to gather, post and share ideas and other resources. The opportunity given by M-learning would afford the learners of the chance of using authentic English language that would make it possible for them to construct their own knowledge. The integration of M-learning in to the teaching of English in secondary schools would afford the learners the opportunity of having a method that is $21^{\text {st }}$ century compliant and availing the learners the digital age benefits. To fully enjoy the benefits offered by this innovation, the schools must be given some infrastructural face lifts in terms of good network connection and stable electricity. 


\section{REFERENCES}

[1] Al-Mutawa, N. and Kailani, T. (1989). Methods of teaching English to Arab students. Longman Group Ltd.

[2] BBC NEWS (2011). Africa mobile phone industry 'booming'. Retrieved August 20 ${ }^{\text {th }}, 2012$ from www.bbc.co.uk/news/worldafrica-1565998.

[3] Brown, T. (2005). Towards a model for m-learning in Africa. International Journal on E-Learning, 4(3), 299-315.

[4] Clarke, P., Keing, C., Lam, P., \& McNaught, C. (2008). Using smss to engage students in language learning. In E. R. Weipp \& J. Luca (Eds.), ED-MEDIA 2008 (pp. 6132-6141). Proceedings of the 20th annual World Conference on Educational Multimedia, Hypermedia \& Telecommunications, Vienna, Austria, 30 June-4 July. Chesapeake VA: Association for the Advancement of Computers in Education

[5] Duncan-Howell \& Lee. (2007). M-learning: Finding a place for mobile technologies within tertiary educational settings. Retrieved June1 $1^{\text {th }}, 2012$ from www.ascilite.org.au/conferences/singapore07/procs/duncan-howell.pdf.

[6] Gaudry-Perkins, F \& Dawes, L. (2011). A powerful tool for addressing MDGs. Retrieved 2012 from www.mdg-review.org.

[7] Geddes, S.J. (2004). Mobile learning in the $21^{\text {st }}$ Century: Benefit to learners. Retrieved August $3^{\text {rd }}$, 2012 from http:// knowledgetree.flexible learning.net.au/edition06/download/geddes.pdf.

[8] Hartnell-Young and Nadja Heym. (2008). How mobile phones help learning in secondary Schools. A Report to Becta. Learning Sciences Research Institute University of Nottingham. Retrieved June $29^{\text {th }}, 2012$ from www.isri.nottingham.ac.uk.

[9] ICT Facts and Figures. (2011). ITU world telecommunication/ICT Indicators database. International Telecommunication Union.

[10] Isiaka et al. (2011). Implementing mobile learning in Nigeria tertiary educational system - A feasibility study. International Journal of Science and Advanced Technology (ISSN 2221-8386) Volume 1 No 7 September 2011 Retrieved June18 ${ }^{\text {th }}, 2012$ from http://www.ijsat.com.

[11] Johnson, K., McHugo, C., \& Hall, T. (2006): Analysing the efficacy of blended learning using technology enhanced learning (TEL) and m-learning delivery technologies. Paper presented at the $23^{\text {rd }}$ ASCILITE Conference, Sydney, 3-6 December 2006.

[12] Keegan, D. (2005). Mobile learning: next generation of learning. Distance Educational International. Retrieved June $29^{\text {th }}, 2012$ from http://learning.ericsson.net/mlearning2/files.

[13] Kinshuk. (2003). Adaptive mobile learning technologies. GlobalEducator.com. Retrieved June 23 ${ }^{\text {rd }} 2012$, from http://www.whirligig.com.au/globaleducator/articles/Kinshuk2003.pdf.

[14] Kukulska-Hulme.A., Shield.L, \& Hassan.X. (2010). Mobile technologies for language learning and teaching. An exploratory investigation. In Gimeno Sanz, Ana ed. New Trends in Computer Assisted Language Learning Working Together, Gandia, Spain, Macmillian.

[15] Kweyu, E \& Sevilla, J. (2012). M-learning: delivering elearning content through the mobile. Abstract Presented at $7^{\text {th }}$ International Conference on ICT for Development, Education andTraining, E-learning Africa, May $23^{\text {rd }}$ to $25^{\text {th }}$, 2012. Cotonou, Benin Republic.

[16] Mellow, P. (2005). The media generation: Maximize learning by getting mobile. Paper presented at Ascilite 2005. Retrieved from June $20^{\text {th }} 2012$ from http://www/ascilite.org.au/conference/brisbane05/blog/proceedings/53 Mellow.pdf.

[17] Mohammed and Woollard. (2009). Mobile learning in English language Learning: An implementation strategy for secondary schools in Malaysia. Professional Development Research Centre Conference. Southampton, United Kingdom. Retrieved June $29^{\text {th }}, 2012$.

[18] Nwaocha V.O. (2010). SMS-based mobile learning system: A veritable tool for English language education in rural Nigeria. Paper presented at ICTD2010, $13^{\text {th }}-16^{\text {th }}$ December, Royal Holloway, University of London.

[19] Nyiri, K. (2002). Towards a philosophy of m-learning. Proceedings of the IEEE International Workshop on Wireless and Mobile Technologies in Education. Sweden, August 29-30, 2002.

[20] Nyiri, K. (2005). The Mobile Phone in 2005: Where are we now? Proceedings of Seeing, Understanding, Learning in the Mobile Age. Retrieved January 16, 22006, from http://www.fil.hu/mobil/2005/Nyiri_intr_tlk.pdf.

[21] Oblinger, D. (2004). The next generation of education engagement. Journal of Interactive Media in Education. Special Issue on the Educational Semantic Web. Retrieved June $11^{\text {th }}, 2012$ from www-jime.open.ac. uk/2004/8.

[22] Prensky, M. (2001). Digital natives, digital immigrants. On the Horizon, MCB University Press, Vol. 9 No. 5, October 2001.

[23] Quinn, C. (2000). Learning: mobile, wireless, in-your-pocket learning. LiNE Zine. Learning in the New Economy Magazine. Retrieved July $18^{\text {th }} 2012$ from http:www.linezine.com/2.1/features/cqmmwiyp.htm.

[24] Roschelle, J. (2003). Unlocking the learning value of wireless mobile devices. Journal of Computer Assisted Learning, 19(3), 260-272.

[25] Sebbowa D. (2011). Using mobile phone forums to enhance interactivity in teaching: A case of Makerere University. An abstract Presented at $7^{\text {th }}$ International Conference on ICT for Development, Education and Training, E-learning Africa 2012, Cotonou.

[26] Stead, G. (2005). Moving mobile into the mainstream. Paper presented at the 4th world conference on mLearning. Retrieved February $19^{\text {th }}, 2013$ from http:www.mlearn.org.za/CD/papers/Stead.pdf.

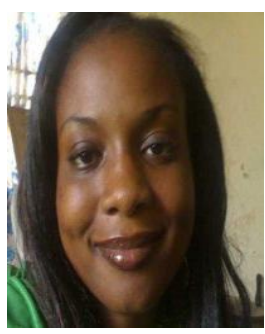

Ogunduyile, Abimbola. O was born in Zaria, Kaduna State, Nigeria, West Africa. She got a B.A (Hons) English and Literature from the University of Benin, Nigeria in 2003; then an M.A English from the University of Ibadan, Nigeria in 2009. She is an Assistant Lecturer in the Federal University of Technology, Akure, Nigeria. She is interested in stylistics, language teaching and learning using mobile technologies. 